\title{
Synthesis and Antimicrobial Activity of Azepine Analogue of Lignan
}

\author{
Ashok Kumar Singh ${ }^{*}$ \\ Department of Chemistry, Tri-Chandra Multiple Campus, Tribhuvan University, Nepal \\ Email: asokksingh@yahoo.co.in
}

\begin{abstract}
Diphenylamine (1) was condensed with maleic anhydride (2) in the presence of sodium hydride and dry benzene, 4-N,N-diphenyl amine-4-oxo-2-butenoic acid (3) was achieved. Intramolecular cyclization of compound 3 with PPE afforded 1-phenyl-1H-benzo[b] azepine-2,5 dione (4).
\end{abstract}

Keywords: Diphenylamine, azepine, podophyllotoxin,

\section{Introduction}

Seven membered heterocycles constitute an important class of compounds that have found many applications in medicinal chemistry ${ }^{1}{ }^{2}$ Some aza analogues of podophyllotoxin bearing an extended ring have been reported in literature, which are named as azapines ${ }^{3}$ and they have exhibited low cytotoxic activity ${ }^{4}$. 2,3-benzodiazepine analogues act as highly selective noncompetitive antagonists and also possess anticonvulsant activity. Structure activity relationship study pointed out that the anticonvulsant activity of compounds depends on dimethoxy benzene moiety ${ }^{5}$. Benzazepine analogues are of significant interest due to their pharmacological activity against dopamine and other biological receptors ${ }^{6}$. Recently 1,3,4,5-tetrahydro-2H-3-benzazepine-2-one was synthesized from 2-(4-hydroxy-3-methoxy-phenyl)-N(2-hydroxy-2-phenyl-ethyl)-N-methyl-acetamide using methanesulphonic acid ${ }^{7}$.

Benzodiazepine is a type of psychotropic drug, which affect the mind and can also alter mood. Benzodiazepine has been used therapeutically as anxiolytic (drug to relieve anxiety), as tranquilizer and exhibited advantageous anticonvulsant properties, ${ }^{8}$. In view of extensive biological activities of benzazepine analogues, a facile synthesis of 1-phenyl-1H-benzo[b] azapine-2,3-dione (4), from diphenylamine-4-oxo-2-butenoic acid (3) using PPE has been undertaken and tested for antimicrobial activity against the pathogens.(scheme-1).

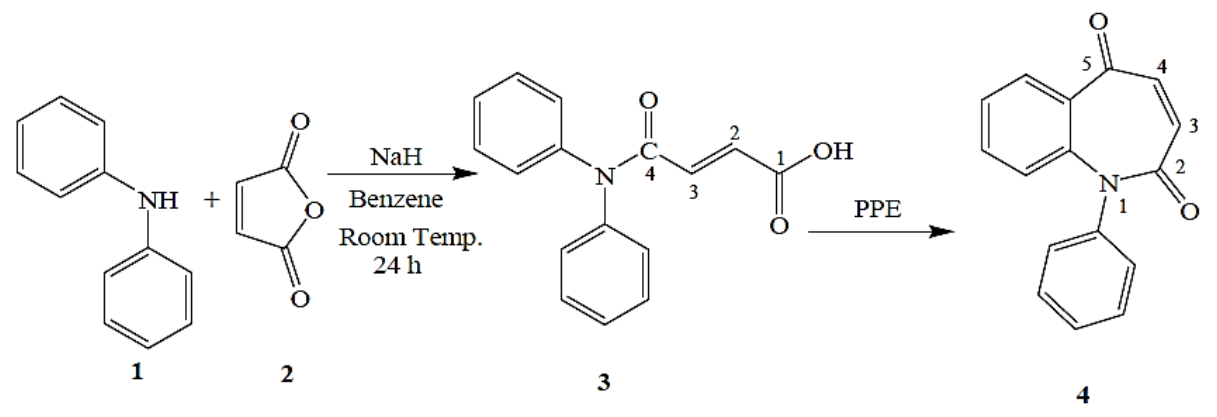

Scheme 1

* Corresponding author 


\section{Experimental}

\section{A typical procedure for 4-N,N-Diphenyl amine-4-oxo-2-butenoic acid (3)}

Sodium hydride $(0.24 \mathrm{~g}, 0.01 \mathrm{~mol})$ in dry benzene $(15 \mathrm{ml})$ was stirred for $15 \mathrm{~min}$. Then Powdered maleic anhydride $(2,1.0 \mathrm{~g}, 0.01 \mathrm{~mol})$ was added to the reaction mixture and stirred for $24 \mathrm{~h}$. The reaction mixture was diluted with equal volume of water. The benzene layer along with precipitate was separated from aqueous layer. The benzene layer was extracted with $5 \%$ of $\mathrm{NaHCO}_{3}$ and acidified with $2 \mathrm{~N} \mathrm{HCl}$. The precipitate was filtered and the crude solid was recrystallized from ethanol to achieve $\mathbf{3}$ as white solid in $70 \%(1.87 \mathrm{~g})$ yield.

M.P. $130-131^{\circ} \mathrm{C}$

IR (Nujol): $1650(\mathrm{C}=\mathrm{O}), 1720$ (acid C=O), 3320-3430 $\mathrm{cm}^{-1}(\mathrm{OH})$

${ }^{1}$ HNMR (DMSO-d $\left.)_{6}\right): 6.4\left(\mathrm{~d}, J=6 \mathrm{~Hz}, 1 \mathrm{H}, \mathrm{C}_{2}-\mathrm{H}\right), 7.2\left(\mathrm{~d}, J=6 \mathrm{~Hz}, 1 \mathrm{H}, \mathrm{C}_{3}-\mathrm{H}\right), 7.3-7.65(\mathrm{~m}, 10 \mathrm{H}, \mathrm{Ar}-\mathrm{H}), 9.8$ (bs, $1 \mathrm{H}, \mathrm{COOH})$

MASS (m/z, \% abundance): $268\left(\mathrm{M}^{+}+1,100\right), 267\left(\mathrm{M}^{+}, 16\right), 250$ (55), 222 (33), 170 (44), 99 (11)

Anal. Calcd. for $\mathrm{C}_{16} \mathrm{H}_{13} \mathrm{NO}_{3}$ : C, 71.90; H, 4.90; N, 5.24; Found: C, 71.99; H, 4.80; N, 5.35\%.

\section{A typical procedure for 1-Phenyl-1H-benzo[b] azepine-2,3dione}

Compound $(3,1.34 \mathrm{~g}, 5 \mathrm{~m} \mathrm{~mol})$ in PPE $(20 \mathrm{ml})$ was refluxed for $3 \mathrm{~h}$ at $80^{\circ} \mathrm{C}$ and then stirred at room temperature for overnight. The reaction mixture was diluted with cold water and extracted with chloroform $(3 \times 20 \mathrm{ml})$. The organic layer was washed with $5 \%$ sodium bicarbonate $(3 \times 20 \mathrm{ml})$ and washed with water $(3 \times 20 \mathrm{ml})$. The organic layer was dried over anhydrous sodium sulphate and evaporated to dryness. The crude solid was recrystallized with ethanol to achieve $\mathbf{4}$ as a pale green solid in $72 \%(0.9 \mathrm{~g})$ yield.

M.P. $110-112^{\circ} \mathrm{C}$

IR (Nujol): $1655 \mathrm{~cm}^{-1}(\mathrm{C}=\mathrm{O})$

${ }^{1}$ HNMR (CDCl $\left.\mathbf{C}_{3}\right): 7.05\left(\mathrm{~d}, J=6 \mathrm{~Hz}, 1 \mathrm{H}, \mathrm{C}_{3}-\mathrm{H}\right), 7.1-7.85(\mathrm{~m}, 9 \mathrm{H}, \mathrm{Ar}-\mathrm{H}), 7.6\left(\mathrm{~d}, J=6 \mathrm{~Hz}, 1 \mathrm{H}, \mathrm{C}_{4}-\mathrm{H}\right)$

$\operatorname{MASS}\left(\mathbf{m} / \mathbf{z}, \%\right.$ abundance): $250\left(\mathrm{M}^{+}+1,30\right), 249\left(\mathrm{M}^{+}, 5\right), 221(100), 205$ (30)

Anal. Calcd. for $\mathbf{C}_{16} \mathbf{H}_{11} \mathbf{N O}_{2}$ : C, 77.10; H, 4.45; N, 5.62; Found: C, 77.20; H, 4.50; N, 5.72\%.

\section{Results and Discussion}

The strategy in the synthesis of desired compounds is as follows. Diphenylamine (1) was condensed with maleic anhydride (2) in the presence of sodium hydride and dry benzene, 4-N,N-diphenyl amine-4oxo-2-butenoic acid (3) achieved. Intramolecular cyclization of compound 3 with PPE afforded 1phenyl-1H-benzo[b] azepine-2,5 dione (4).

4-N,N-Diphenyl amine-4-oxo-2-butenoic acid (3) was obtained in good yield, by heating a mixture of diphenyl amine (1), maleic anhydride (2) and sodium hydride in presence of dry benzene. PPE has been used as a good cyclodehydrating agent in many heterocyclic syntheses. The compound $\mathbf{3}$ was cyclized to the corresponding azepine derivative $\mathbf{4}$ by heating with PPE.

The structure of all compounds was supported by IR, ${ }^{1} \mathrm{NMR}$ data and microanalysis. The IR spectrum of compound 3 showed keto carbonyl, acid carbonyl and $\mathrm{OH}$ stretching frequencies at 1650 , 1720 and 3320-3430 $\mathrm{cm}^{-1}$ respectively. On the other hand, ${ }^{1} \mathrm{H}$ NMR spectrum showed absorption as two doublets at $\delta 6.4$ and 7.2 and a multiplet in the range $\delta 7.0-7.65$ assigned to $\mathrm{C}_{2}-\mathrm{H}, \mathrm{C}_{3}-\mathrm{H}$ and aromatic protons respectively. In addition, it showed a broad singlet at $\delta 9.8$ assigned to hydroxy protons. Mass spectrum of compound 3 showed the molecular ion peak at 267 
In IR spectra compound 4 showed absorption at 1655 due to keto group stretching. Similarly in ${ }^{1} \mathrm{H}$ NMR spectra it showed two doublets at $\delta 7.05$ and 7.6 due to $\mathrm{C}_{3}$ and $\mathrm{C}_{4}$ protons of azepine dione ring. In addition, it showed a multiplet in the range $\delta$ 7.1-7.85 due to aromatic protons. In mass spectra of compound 4 showed the molecular on peak at 249.

\section{Antimicrobial activity}

The compound 4 was screened for antimicrobial activity using cup plate method ${ }^{10,11}$. The activity was carried out against three pathogenic bacteria, B. Cereus, S. Aureus and E. Soli and two fungal culture, F. Solani, A. Favus. The standard drugs used were Chloromycetin and Griseofulvin. The compound was tested in dimethyl formaide. The zone of incubation was compared with standard drug after $43 \mathrm{hr}$ of incubation at $37^{\circ}$ for antibacterial activity and $36 \mathrm{hr}$ at $37^{\circ}$ antifungal activity. Antimicrobial activity screening results are summarized in Table 1 and 2.

Table 1: Antibacterial activity

\begin{tabular}{|ccccccc|}
\hline Compd. & $\begin{array}{c}\text { B. cereus } \\
\text { Area of } \\
\text { inhibition } \\
\mathrm{mm}^{2}\end{array}$ & $\begin{array}{c}\text { Relative } \\
\text { \% of } \\
\text { inhibition }\end{array}$ & $\begin{array}{c}\text { Area of } \\
\text { inhibition } \\
\mathrm{mm}^{2}\end{array}$ & $\begin{array}{c}\text { Relative } \\
\% \text { of } \\
\text { inhibition }\end{array}$ & $\begin{array}{c}\text { Area of } \\
\text { inhibition } \\
\mathrm{mm}^{2}\end{array}$ & $\begin{array}{c}\text { Relative\% } \\
\text { of } \\
\text { inhibition }\end{array}$ \\
\hline $\mathbf{8 9}$ & 353 & 96 & 420 & 91 & 100 & 98 \\
\hline
\end{tabular}

Table-2: Antifungal activity of Compound 4

\begin{tabular}{|ccccc|}
\hline Compd. & \multicolumn{2}{c}{ F. Solani } & \multicolumn{2}{c|}{ A. Flavus } \\
& $\begin{array}{c}\text { Area of } \\
\text { inhibition } \\
\mathrm{mm}^{2}\end{array}$ & $\begin{array}{c}\text { Relative } \\
\text { \% of } \\
\text { inhibition }\end{array}$ & $\begin{array}{c}\text { Area of } \\
\text { inhibition } \\
\mathrm{mm}^{2}\end{array}$ & $\begin{array}{c}\text { Relative } \\
\% \text { of } \\
\text { inhibition }\end{array}$ \\
\hline $\mathbf{4}$ & 226 & 78 & 256 & 88 \\
\hline
\end{tabular}

\section{Conclusion}

The compound 1-phenyl-1H-benzo[b]azepine-2,5-dione has shown considerable activity against $F$. Solani and A. Flavus fungal strains.

\section{Acknowledgements}

Author would like to express sincere thanks to Dr. Satish, lecturer, Department of Studies in Botany, University of Mysore, Manasagangotri, Mysore for his help in recording the biological activity for synthesized compound. 


\section{References}

1. Smalley R. K., “Azepines: Benzo-, Dibenzo- and Tribenzoazepines” in Methods Org. Chem. (Houben-Weyl), Hetarenes IV: Six-Mwmbered and Larger Hetero Rings with maximum Unsaturation, 1997, Ed. 9, 207.

2. Hagan D. O., Nat. Prod. Rep., 1997, 14, 63.

3. Laatsch H., Erust, B.P. and Hoffmann D. Liebigs Ann. 1995, 1733.

4. Stephanie Desbene and Sylviane Giorgi-Renault, Curr. Med. Chem. -Anti-cancer Agents, $2002,2,71$.

5. (a) Chimirri, A, Gitto, R. and Zappala M., Exp. Opin The. Pattents, 1999, 9, 557. (b). De Sarro G., Chimirri, A., De Sarro A., Gitto, R., Grasso S., Gusti P. and Chapman A. G., Eur. J. Pharmacol., 1995, 294, 411. (c). Chimirri, A., De Sarro G., De Sarro A., Gitto, R., Grasso S., Quartarone S., Gusti P., Libri V., Constanti A. and Chapman A. G., J. Med. Chem., 1997, 40, 1258.

6. (a). Bourne J. A Recent reviews of 3-benzazepines: CNS Drug Reviews, 2001, 7, 399. (b). Kawase M; Saito S.; Motohashi N. Int. J. Antimicrob. Agents, 2000, 14, 193.

7. Cobb J. E., Nanthakumar, S. S., Rutkowske R. and Uehling, D. E., Synlett., 2004, 1394.

8. McKernan R. M. and Whiting P. J., Trends in Neurosci, 1996, 19, 139.

9. Rudolph U. Koop C and Keist R., Nature, 1999, 401, 796.

10. Saundane A.R.; Rudresh K.; Satyanarayana N.D.; Hiremath S.O. Ind. J. Pharm. Sci., 1998, 60, 379.

11. Seely H. W.;Van Demark P. J; Microbes in Action; A Laboratory Mannual of Microbiology, Taraporewala D. B., Bombay, $2^{\text {nd }}$ edn., 1975, 55, 80. 